\title{
Research in School Shootings
}

\author{
Glenn W. Muschert*
}

Miami University

\section{Abstract}

Studies of school shootings have been conducted in a variety of disciplines, including sociology, psychology, and media studies. However, to date there is no unified body of knowledge about such events. In an effort to synthesize past studies, and to orient future studies in school shootings, this article (i) offers a typology for understanding the varieties of school shooting incidents, including rampages, mass murders, terrorist attacks, targeted attacks, and government shootings; (ii) examines the mass media dynamic of school shootings; and (iii) presents a synthesis of the multilevel causes suggested in the research, including those on the individual, community, and social levels. Suggestions for future studies in school shootings are explored.

\section{Introduction}

School-related shootings, particularly those that are dramatic in nature, evoke strong public outcry, and justifiably so. Following an apparent spate of incidents occurring between 1997 and 2001, it seemed as if the USA was on the brink of a moral panic concerning delinquency and nihilistic youth culture. Since then, "Columbine has become a keyword for a complex set of emotions surrounding youth, risk, fear, and delinquency in 21st century America' (Muschert 2007). One alarmist (Stein 2000) went so far as to label Columbine as a metaphor for a contemporary crisis of youth culture.

Cutting through the hype and public emotion about school shooting, in the background social scientists have been at work in trying to tease out the varying dimensions of this phenomenon. Despite the widely diffused recognition and fear associated with violence in schools, empirical evidence indicates that schools are among the safest places for children, compared to their homes and neighborhood environs. The high level of attention given to school shootings, compared to other forms of victimization in schools, is potentially misleading. The most current data about victimization in schools during the 2004-05 school year indicated that nonfatal incidents were many times more common, including victimization rates of 33 thefts and 22 violent crimes, including 4 serious violent crimes, per 1000 students. In comparison, fatalities in schools are 
Figure 1. Homicides and Suicides of Youth Ages 5-18 at School, 1992-2005 (Source: Dinkes et al. 2006, 7).

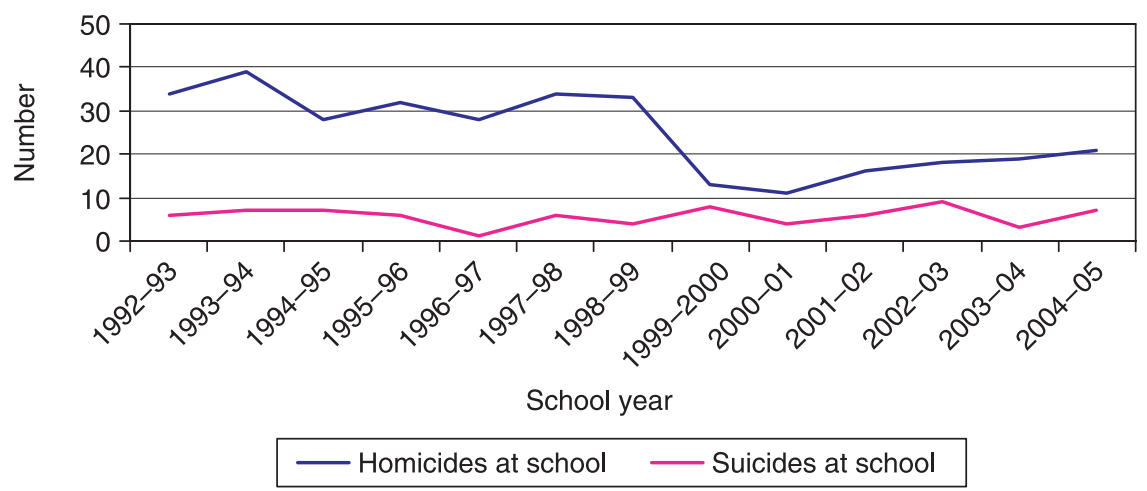

extremely rare: only about 1 in 2,000,000 school-age youth will die from homicide or suicide at school each year. Less than $2 \%$ of homicides of school-age youth occur at school, and even as the public concern about school shootings peaked, the incidence of violent deaths in schools subsequently declined (Dinkes et al. 2006) as illustrated in Figure 1.

When it comes to school shootings, how is it possible that the public perception and sociological evidence so drastically diverge? It seems that perceptions about school shootings are an example of the Rashomon effect, which refers to the subjective construction of reality in which observers of a single event perceive incompatible, yet plausible versions of what happened. First suggested by Heider (1988), the term Rashomon effect is derived from the title of a 1951 film by the Japanese director Akira Kurosawa in which four characters who witnessed a crime later describe the event in different and contradictory ways. Unlike more traditional detective films, in which a single unified truth ultimately emerges, the complex message of Rashomon emerges when viewers are left to decide for themselves which, if any, of the four characters is telling the truth. Alternately, viewers may choose to construct their own truth by synthesizing the divergent accounts (Kurosawa 1969).

A similar Rashomon effect occurs when school shootings are discussed, in that those seeking to understand such incidents hear varying claims about what occurs. Certainly, there is a strong mass media dynamic occurring, and the characteristics of school shootings reported in the media are frequently different than those reported in social science research. At the turn of the millennium, school shootings were an ascendant social problem, often because the events garnered public interest, which contributed to the perception that school shootings were a new form of violence occurring with increased frequency and intensity. 
Table 1. Typology of School Shootings

\begin{tabular}{|c|c|c|c|}
\hline $\begin{array}{l}\text { Incident } \\
\text { type }\end{array}$ & Perpetrator & Motive & Exemplary cases \\
\hline $\begin{array}{l}\text { Rampage } \\
\text { shootings }\end{array}$ & $\begin{array}{l}\text { Member or former } \\
\text { member, such as } \\
\text { a student, former } \\
\text { student, employee, } \\
\text { or former employee }\end{array}$ & $\begin{array}{l}\text { Attack on school or } \\
\text { group of students } \\
\text { selected for } \\
\text { symbolic } \\
\text { significance, often } \\
\text { to exact revenge on } \\
\text { a community or to } \\
\text { gain power. }\end{array}$ & $\begin{array}{l}1966 \text { Texas Tower } \\
\text { shootings } \\
1999 \text { Columbine High } \\
\text { School shootings in } \\
\text { Littleton, CO } \\
2002 \text { Erfurt Secondary } \\
\text { School shooting in } \\
\text { Germany } \\
2007 \text { Virginia } \\
\text { Tech shootings }\end{array}$ \\
\hline $\begin{array}{l}\text { Mass } \\
\text { murders }\end{array}$ & $\begin{array}{l}\text { Non-member, typically } \\
\text { an adult perpetrator, } \\
\text { who is not a former } \\
\text { student or employee }\end{array}$ & $\begin{array}{l}\text { Attack on school } \\
\text { institution or group } \\
\text { of students for } \\
\text { symbolic } \\
\text { significance, often } \\
\text { to gain power. }\end{array}$ & $\begin{array}{l}1927 \text { Bath School } \\
\text { Disaster in Bath, MI } \\
1989 \text { Montréal } \\
\text { massacre } \\
1996 \text { Dunblane school } \\
\text { massacre in Dunblane, } \\
\text { Scotland }\end{array}$ \\
\hline $\begin{array}{l}\text { Terrorist } \\
\text { attacks }\end{array}$ & $\begin{array}{l}\text { Individuals or groups } \\
\text { engaging in violent } \\
\text { acts to advance political } \\
\text { or ideological goals }\end{array}$ & $\begin{array}{l}\text { Politically motivated } \\
\text { attack on school or } \\
\text { group of students } \\
\text { selected for their } \\
\text { symbolic } \\
\text { importance. }\end{array}$ & $\begin{array}{l}1974 \text { Ma'a lot terrorist } \\
\text { attack in Ma'a lot, Israel } \\
2004 \text { Beslan terrorist } \\
\text { attack in Beslan, Russia }\end{array}$ \\
\hline $\begin{array}{l}\text { Targeted } \\
\text { shootings }\end{array}$ & $\begin{array}{l}\text { Member or former } \\
\text { member, such as a } \\
\text { student, former } \\
\text { student, employee, } \\
\text { or former employee }\end{array}$ & $\begin{array}{l}\text { Revenge targeted } \\
\text { at individuals } \\
\text { for some real or } \\
\text { perceived } \\
\text { maltreatment. }\end{array}$ & $\begin{array}{l}1992 \text { Tilden High } \\
\text { shooting in Chicago, IL } \\
2003 \text { Red Lion shooting } \\
\text { in Red Lion, PA }\end{array}$ \\
\hline $\begin{array}{l}\text { Government } \\
\text { shootings }\end{array}$ & $\begin{array}{l}\text { Government agent } \\
\text { such as military or } \\
\text { police }\end{array}$ & $\begin{array}{l}\text { Response to } \\
\text { student protest or } \\
\text { riot behavior, often } \\
\text { in response to } \\
\text { a crisis of } \\
\text { government } \\
\text { legitimacy. }\end{array}$ & $\begin{array}{l}1968 \text { shootings at } \\
\text { South Carolina } \\
\text { State University } \\
1970 \text { shootings at } \\
\text { Kent State University }\end{array}$ \\
\hline
\end{tabular}

To compound the problem, there is a further Rashomon effect that stems from the variety of cases examined (Heider 1988) and the divergent scholarly points of view from which school shootings have been studied (Roth and Mehta 2002). Instead of contributing to a broad, multidisciplinary perspective on school shootings as a social problem, such a disjuncture among scholars means that little in the way of unified scholarship has emerged. In an attempt to survey and synthesize the varying scholarly perspectives about school shootings, this article presents a typology of 
school shooting events and explores the underlying mass media dynamic involved. The article then surveys the research about school shootings highlighting the individual, community, and wider social causes of these events. The concluding remarks reassess the future social science research agenda on school shootings, with suggestions for especially fruitful avenues of research.

\section{Definition and typology}

An initial requirement is to define the phenomenon of school shootings and the subcategories of incidents, teasing out the varying motives and identities of the perpetrators of school shootings. While rampage attacks are the variety of school shooting incidents that have captured the lion's share of mass media attention in the last decade, a broader historical perspective reveals a variety of school-related shooting incidents. As detailed in Table 1, this article offers a typology, including five varieties of schoolrelated shooting incidents: rampage shootings, school-related mass murders, terrorist attacks on schools or school children, school-related targeted shootings, and government shootings taking place at schools. Key operational elements of the typology include the in-group/out-group status of the perpetrator(s), and whether victims were specifically targets or selected for symbolic reasons. For each type, exemplary cases are offered, more because they are well known, than because they necessarily epitomize the type. In most cases, the examples are well known because they were severe.

Rampage shootings are among those that have recently attracted the most public attention. These are expressive, non-targeted attacks on a school institution. 'An institutional attack takes place on a public stage before an audience, is committed by a member of former member of the institution, and involves multiple victims, some chosen for their symbolic significance or at random. This final condition signifies that it is the organization, not the individuals, who are important' (Newman 2004, 231). Frequently, the motivations for rampage shootings are to attain power or to exact revenge on the community or large groups within the community, and the rampage shooter has also been labeled in the literature as the classroom avenger (McGee and DeBernardo 1999). Many perpetrators equate their target schools with the communities where they are located, and the rationale of attacking the school can be understood as an attempt to attack the community. The 1999 Columbine shootings in Littleton, Colorado, is the archetypical case occurring in the USA, where two students attempted to blow up their school, ultimately killing 15 (Muschert and Larkin forthcoming). While most rampage shootings studied have occurred in high schools or middle schools, some shootings occurring at universities also fit this category. The 1966 University of Texas tower shootings and the 2007 shootings at Virginia Tech are wellrecognized examples of rampage incidents that occurred at universities. 
A second category is the school-related mass murder incident, typically carried out by an individual who targets categories of individuals or the school institution in general. School-related mass murders are a subset of mass murder incidents, where an adult perpetrator, who is not a current or former student or employee, targets a school institution or group of students, selected for their symbolic importance. As in rampage cases, such incidents are sometimes labeled 'postal-type shootings', and are typically carried out by individuals, motivated by desires for power, revenge, or a perverted sense of loyalty (Levin and Fox 1999). Although it is not technically a shooting incident, the worst school violence incident in US history fits the mass murder category. In 1927, a farmer killed his wife, blew up every building on their farm, and then detonated explosives placed under the Bath, Michigan, school building, killing a total of 45 people. The attack seems to have been motivated by the desire for revenge for a newly levied school tax (Ellsworth 1927). Outside the USA, the 1989 shooting at the École Politechnique de Montréal in Canada (also known as Montréal Massacre) also qualifies as a mass murder. Engineering student Marc Lépine entered a classroom, and then separated the male and female students. After claiming that he hated feminists, he shot at the women, killing six (Eglin and Hester 2003).

A third variety of incident involves terrorist attacks, in which a school institution or students are selected as a symbolic target in a politically motivated attack. Since children and schools are important institutions in most communities, such a strike is particularly horrific, and may be effective in gaining attention for the terrorist groups. Noteworthy examples include the 1974 incident in Ma'alot, Israel, where three terrorists held students in an elementary school hostage, demanding the release of political prisoners. Before the attack ended, 25 people died, including 21 children (Jacoby 2004). In 2004, terrorists took 1200 people hostage at a school in Beslan, Russia. After 3 days, Russian security stormed the building, and 344 people died, including 186 children (Dunlop 2006).

A fourth variety of school shootings are school-related targeted incidents, where a member or former member of the institution specifically attacks an individual or group of individuals in order to exact revenge for some real or perceived mistreatment. Unlike a rampage shooting, a targeted attack is not a symbolic attack on the entire school. For example, the 1992 incident at Tilden High in Chicago that resulted in the death of a student was gang related (Hagan et al. 2002). Another incident that fits this category is the 2003 shooting in Red Lion, Pennsylvania, where a student fatally shot a school administrator (CNN 2003). While many schoolrelated shootings are of the targeted variety, such incidents often fail to garner widespread media attention.

A final variety of school-related shootings are those that involve government agents as perpetrators, such as police or military personnel. This category typically involves government agents' use of violence in response to 
student protest or riot behaviors. Noteworthy incidents in the USA include the 1968 shooting of antisegregation protesters by South Carolina Highway Patrol officers that occurred at South Carolina State University, also know as the Orangeburg Massacre (Nelson and Bass 1970). Better known is the 1970 shooting of four students by Ohio National Guard troops at Kent State University, as they protested the US invasion of Cambodia during the Vietnam War (Caputo 2005). Such attacks may signal public unrest coupled with a crisis of legitimacy for government institutions as the 1989 Tiananmen Square incident when student-led protesters were gunned down by the Chinese military. In other cases, such incidents may result from government agents' panicked responses to protest behaviors, as in the Kent State shootings.

Of the five varieties of school shootings, much of the recent attention surrounding school-related shootings has focused on the rampage, mass murder, and targeted varieties of attacks. Although the school-related terrorist attacks and government attacks do occur, it was the perceived wave of rampage school shootings occurring in the late 1990s and early 2000 s that motivated much of the recent social science research.

\section{Mass media and school shootings}

Mass media play an integral role in the public perception of school shootings as a social problem, and social scientists have examined the media framing of school shooting incidents. When it comes to understanding the mass media dynamic related to social problems, it is worth pointing out that the profit motive behind news production may obfuscate a deep understanding of social problems and constructive generation of solutions. Frequently, journalists are caught between the need to garner attention for a profit-oriented industry and the need to maintain the ethical standard of their profession. At times, journalists highlighted the dramatic elements of school shootings, thereby undermining a sober, longer-term examination of school shooting phenomena as a whole.

The media dynamic of the Rashomon effect surrounding school shootings stems from the fact that most people experience school shootings as a mass-mediated phenomenon, rather than directly. While the problem of school-related shootings occurred across history, it was the intense media coverage of the famous incidents, including West Paducah, Kentucky; Jonesboro, Arkansas; and Littleton, that created the public perception of school shootings as an emergent and increasing social problem. Thus, the school shooting problem as broadly recognized had more to do with the media coverage of recent incidents than actual changes in levels of violence in schools. Much of this attention concentrated on rampage-type incidents.

To understand the rise of the perceived school shooting problem, it is important to understand the broader social discourse surrounding youth 
and delinquency in the decade before rampage shootings became widely discussed. David Altheide (2002a) discussed the emergence in the 1980s of the connected discourses of childhood and fear that peaked in 1994, an important historical context regarding the problem of school-related violence that garnered attention in the late 1990s and early 2000s. These concerns reflected public anxiety over crime and disaster, and public outcry surrounding school shootings was a permutation of this calculus of fear (Burns and Crawford 1999; Glassner 1999). Muschert and Carr (2006) tracked the emergence of the school shooting as an issue of national significance in the USA, and found that school shootings first became recognized as a social problem in 1997. Prior to that time, incidents were largely characterized as local in their relevance and impact. The analysis revealed that the socially constructed rampage shooting problem peaked around 1999, roughly coinciding with the 1999 Columbine shootings in Colorado.

At the peak of public interest in school shootings as a social problem, news media coverage was intense. Readers wishing to understand the media coverage of school shootings might begin with the summative, non-technical study on the media content of school violence published by the Center for Media and Public Affairs (1999), which examined the media's characterization of the shooters, communities, causes, and suggested solutions for the problem of school shootings. In addition, Bonilla (2000) produced an edited work, including articles from news media and popular magazines, in which readers can examine the news discourse firsthand.

Starting in 2001, the school shooting problem began its decline as a national concern, and incidents were once again most strongly characterized as relevant to the communities in which they occurred (Muschert and Carr 2006). Although school shootings are still newsworthy and do garner media attention, they are somewhat less intensely discussed and the duration of discussion tends to be brief. In the US terrorism, the economy, and foreign military involvement have displaced school shootings as a social problem on the public agenda. When compared with the 19972001 period in which the media characterized school shootings as a social problem of national concern, between 2001 and 2006 school shooting events no longer attracted the intense interest from the media. Following the 2007 shootings at Virginia Tech, it is possible that we will see resurgence in the media focus on issues related to campus crime and safety.

Scholars from a variety of disciplines have examined aspects of the media dynamic evident in the phenomenon of school shootings. For example, Maguire et al. (2002) examined the relative levels of media attention garnered by various shooting incidents. Two studies (Haider-Markel and Joslyn 2001; Lawrence and Birkland 2004) found that the mass media tended to characterize school shootings as a problem emerging from inadequate gun control legislation, while Samuels (2000) argued that the Columbine shooters' actions were guided by the logic of contemporary 
entertainment media. Lawrence and Birkland (2004) found that political discourse identified mass media as the catalyst for shooting incidents, but Scharrer et al. (2003) demonstrated that the news media tends to absolve itself from responsibility for school shooting incidents. Because of its status as the best-known and most intensely discussed school shooting incident to occur in recent decades, Columbine has been the subject of numerous media studies. Two studies (Chyi and McCombs 2004; Muschert forthcoming) examined the framing of Columbine as an event of national import, while Lawrence (2001) argued that Columbine was so powerful that it defines the problem of school shootings. Muschert (2007) examined the media's coverage of the Columbine victims, and Ogle et al. (2003) examined the role of clothing and style in the Columbine coverage. Smit (2001) examined Columbine in the media as an example of spectacle, while Gunn and Beard (2003) found that coverage of events like Columbine was taking on an increasingly apocalyptic tone. Other scholars focused on specific social issues in the media coverage of school shootings, including race (Aitken 2001), masculinity (Aitken 2001; Consalvo 2003), and religion (Muschert 2007; Watson 2002). Media studies of other incidents are notably absent from the literature, although Eglin and Hester (2003) and Muschert and Carr (2006) are exceptions. Another interesting variation is Daniels et al. (2007), which examines the media coverage of averted school rampages.

\section{Social science research}

In a brief article that appeared in the wake of the Columbine shootings, Kleck (1999) argued that the attention garnered by such cases is counterproductive to the sober, generalizable study of crime and delinquency. Although the relatively brief attention given by the media and public to the social problem of school shootings may have served as an impediment to the sociological study of more common forms of youth offense and victimization, the notoriety of Columbine-type events has spurred a number of studies in school shootings. However, once again there is an apparent Rashomon effect that might confound those seeking to understand the causes of such events. Scholars have studied a variety of cases from a variety of academic perspectives, and there is a lack of integration across disciplines.

A variety of causes may contribute to school shootings, and therefore no single dynamic is sufficient to explain all, or even a subset, of such events. The causes may emerge from a variety of levels, ranging from the individual causes, community contexts, and social/cultural contexts in which the events occur. The reader might understand the individual factors and community contexts as being among the more proximate causes for school shooting events, while the social/cultural contexts may less directly cause individual school shootings. Nonetheless, the culture 
serves as a general backdrop for school shooting incidents, even if direct causality may not be established.

Among the causes presented in Table 2, only one of the causes is necessary for a school shooting to occur: the availability of guns. All other causes may be understood as frequently contributing to the problem of school shootings, but none of them alone is sufficient to cause a school shooting to occur. Individual causes may be present with varying intensity in some cases, but may be absent in other cases. Indeed, some of the causes suggested may be exclusive of others, as in the cases there tightly knit communities are identified as a context conducive to school shootings (Newman 2004) versus another case where a deracinated community setting is identified (Larkin 2007). School shooting incidents need to be understood as resulting from a constellation of contributing causes, none of which is sufficient in itself to explain a shooting. The fact that many researchers have focused on a single causal dynamic has contributed to the lack of integration in the field.

Table 2. Causes of School Shootings Suggested in Social Science Studies

\begin{tabular}{|c|c|c|}
\hline Level & Category & Specific contributing causes \\
\hline \multirow[t]{5}{*}{$\begin{array}{l}\text { Individual causes } \\
\text { and qualities }\end{array}$} & Mental illness & $\begin{array}{l}\text { Depression, suicidal tendencies, and } \\
\text { mixed personality disorder (McGee } \\
\text { and DeBernardo 1999, 2002; Harding } \\
\text { et al. 2003; Harter et al. 2003; } \\
\text { Sullivan and Guerette 2003) } \\
\text { Fixation on fantasy and weapons, } \\
\text { including violent media } \\
\text { (Meloy et al. 2001) }\end{array}$ \\
\hline & Identity of shooters & $\begin{array}{l}\text { Shootings frequently perpetrated } \\
\text { by males (Mai and Alpert 2000; } \\
\text { Neroni 2000; Newman 2004; } \\
\text { Spiegel and Alpert 2000) } \\
\text { Shootings frequently perpetrated } \\
\text { by whites (Schiele 2001) }\end{array}$ \\
\hline & Access to guns* & $\begin{array}{l}\text { Individual access to firearms and } \\
\text { weapons (Newman 2004) }\end{array}$ \\
\hline & Peer relationships & $\begin{array}{l}\text { Romantic rejection (Klein 2005b) } \\
\text { Victim of bullying (Burgess et al. 2006; } \\
\text { Harter et al. 2003; Kimmel and } \\
\text { Mahler 2003; Klein 2006; Larkin 2007; } \\
\text { Leary et al. 2003; Meloy et al. 2001; } \\
\text { Newman 2004) } \\
\text { Social marginalization of perpetrator } \\
\text { (Newman 2004) }\end{array}$ \\
\hline & $\begin{array}{l}\text { Familial neglect } \\
\text { or abuse }\end{array}$ & $\begin{array}{l}\text { Troubled home situation (Fox et al. } \\
\text { 2003; Newman 2004; Webber 2003a;) }\end{array}$ \\
\hline
\end{tabular}


Table 2. Continued

\begin{tabular}{|c|c|c|}
\hline Level & Category & Specific contributing causes \\
\hline \multirow[t]{5}{*}{ Community contexts } & $\begin{array}{l}\text { Local youth social } \\
\text { dynamics }\end{array}$ & $\begin{array}{l}\text { Exclusionary youth peer group } \\
\text { dynamic (Lickel et al. 2003; Sandler } \\
\text { and Alpert 2000) } \\
\text { Intergroup conflict (Hagan et al. 2003; } \\
\text { Larkin 2007) }\end{array}$ \\
\hline & School contexts & $\begin{array}{l}\text { Poor quality of student/faculty } \\
\text { relationship (Moore et al. 2003) } \\
\text { Inability of school administration to } \\
\text { enforce rules and respond to threats } \\
\text { (Fox and Harding 2005) }\end{array}$ \\
\hline & $\begin{array}{l}\text { Community } \\
\text { cohesion }\end{array}$ & $\begin{array}{l}\text { Tightly knit communities may suppress } \\
\text { response to delinquency (Newman 2004) }\end{array}$ \\
\hline & & $\begin{array}{l}\text { Deracinated communities may be } \\
\text { incapable of responding to } \\
\text { delinquency (Larkin 2007) }\end{array}$ \\
\hline & Community climate & $\begin{array}{l}\text { Intolerant community climate } \\
\text { (Tonso 2003; Aronson 2004; } \\
\text { Larkin 2007) }\end{array}$ \\
\hline \multirow[t]{6}{*}{$\begin{array}{l}\text { Social and cultural } \\
\text { contexts }\end{array}$} & Educational & $\begin{array}{l}\text { Crisis in youth culture educational } \\
\text { institutions, especially public schools } \\
\text { (Catlaw 2000; Cook 2000; Jacobs 2002) } \\
\text { States that allow corporal punishment } \\
\text { in schools (Arcus 2002) }\end{array}$ \\
\hline & Masculinity & $\begin{array}{l}\text { Masculine roles may 'script' violent } \\
\text { behaviors in boys (Mai and Alpert 2000; } \\
\text { Neroni 2000; Newman 2004; Spiegel } \\
\text { and Alpert 2000) }\end{array}$ \\
\hline & & $\begin{array}{l}\text { In some cases, girls are specifically } \\
\text { targeted (CNN 2006; Eglin and Hester } \\
\text { 2003; Webber 2003a, 53-7) }\end{array}$ \\
\hline & Political climate & $\begin{array}{l}\text { Shootings have occurred more } \\
\text { frequently in US states that are } \\
\text { politically conservative (Kimmel and } \\
\text { Mahler 2003) }\end{array}$ \\
\hline & & $\begin{array}{l}\text { Shootings have occurred more } \\
\text { frequently in areas with a strong } \\
\text { conservative religious population } \\
\text { (Arcus 2002) }\end{array}$ \\
\hline & Culture of violence & $\begin{array}{l}\text { Widespread availability and acceptance } \\
\text { of guns (Haider-Markel and Joslyn } \\
2001 \text {; Lawrence and Birkland 2004; } \\
\text { Webber 2003a) } \\
\text { Violence in media as glorifying violence } \\
\text { or sparking copycat crimes (Larkin } \\
\text { 2007; Sullivan and Guerette 2003; } \\
\text { Webber 2003a, 25-43) }\end{array}$ \\
\hline
\end{tabular}

Note: *Access to guns is the only cause that appears in every school shooting case, and is a necessary prerequisite for a school shooting. All other causes appear with varying frequency and intensity in individual incidents. 
This is the essence of the Rashomon effect resulting from disparate attempts to explain school shooting phenomena: that the complexity and variability of school shooting incidents has contributed to confusion among researchers and the general public regarding the causes of these incidents. The fact that school shootings are so complex presents us with one of the more troubling facets of this phenomenon: that there is no realistic way completely to prevent all school shootings. Still, researchers have made notable advances in examining the causes of school shootings. Having presented multilevel causal framework for understanding the phenomenon, the remainder of this section reviews useful resources for further examination of school shooting incidents.

Those seeking non-technical and readable texts for the school shooting problem might select Egendorf (2002), Hunnicut (2006), or Levin and Fox (2001). McCabe and Martin (2005) provide an historical overview of the issue of school violence in the USA from the colonial period to present day, and Henry (2000) offers an integrated definition of school violence phenomena. Repenning et al. (2001) and Cornell (2006) provide overviews of school violence prevention programs. Moore et al. (2003) and Newman (2004) offer more scholarly examinations of the school shooting problem, but which are accessible. In addition, many of the case studies referenced in this section are reader friendly. Scholarly sources include case studies, comparative studies, and publications in sociology and psychology. Social scientists have responded to the public outcry and quest for answers demanded in the wake of high-profile shooting cases. Although much of the academic research has appeared in well-established professional journals, the post-Columbine period also saw the creation of a new scholarly journal specifically intended to cut through the hysteria generated by school shootings: The Journal of School Violence. Since the best-known wave of rampage shootings occurred in the USA, the research on school shootings has a decidedly American focus. In addition, many studies focus disproportionately on the rampage-type incidents, while studies examining the other varieties are relatively rare.

Scholars in sociology and criminology have produced a number of case studies of individual school shooting incidents, including the following rampage incidents: Montréal, Quebec (Eglin and Hester 2003), Springfield, Oregon (Kirk et al. 2000; Webber 2003a), Jonesboro (Fox et al. 2003; Newman 2004; Webber 2003a), West Paducah (Harding et al. 2003; Newman 2004; Webber 2003a), Edinboro (DeJong et al. 2003), Littleton (Larkin 2007; Muschert and Larkin forthcoming), Fort Gibson, Oklahoma (Heck 2001), and Rockdale County (Conyers), Georgia (Sullivan 2002; Sullivan and Guerette 2003). The Encyclopedia of Juvenile Violence (Finley 2007) contains a number of entries referenced by the shooters' names, including Jonesboro, AR; West Paducah, KY; Littleton, CO; Moses Lake, WA; Flint, MI; Rockdale County, GA; Pearl, MS; Edinboro, PA; and Red Lake, MN. In addition, there are a number of studies of targeted 
school violence incidents, including those at New York (Sullivan 2002), East New York (Fullilove et al. 2003), and Chicago (Hagan and Shedd 2002; Hagan et al. 2003).

In addition, there are a number of comparative studies that attempt tease out varying underlying causes. The National School Safety Center (2007) maintains an ongoing report that focuses on each school-associated death as the unit of analysis, which includes 443 cases from August 1, 1992, through January 2007. Although most cases are high school shootings of various types, the study also includes suicides, and non-gun incidents such as stabbings. Deadly Lessons (Moore et al. 2003, 247-342) includes a cross-case analysis of school shooting incidents, and is one of the earliest and most comprehensive studies. Later, Katherine Newman, a contributor to Deadly Lessons, published Rampage, which includes a cross-case analysis of rampage-type school shootings (2004, 229-318). The US Secret Service published two studies (Vossekuil et al. 2000, 2002) covering 37 targeted school shootings involving 41 attackers occurring between 1974 and 2000, including interviews with 10 school shooters. Repenning et al. (2001) attempted to link media coverage, an analysis of five shooting incidents, and subsequent policy initiatives. Other comparative studies have examined varying aspects across multiple school shooting incidents, including gender relations (Kimmel and Mahler 2003; Klein 2005b), political climate (Arcus 2002), media framing (Maguire et al. 2002; Muschert and Carr 2006), the crisis in education (Webber 2003a), and the psychological profile of the shooters (McGee and DeBernardo 1999, 2002; Meloy et al. 2001).

\section{The effects of school shootings}

An aspect of the research that is greatly underemphasized is the effects of school shootings. In rare cases, such as one study that examines the psychological effect of a school shooting on students (Curry 2003), studies may examine the direct effect of such tragedies on their community and its members. However, most research focuses on the wider cultural impact of school shootings. Sociologists have examined the cultural and symbolic importance of school shootings, which have been a source of great public fear (e.g. Altheide 2002b; Burns and Crawford 1999). Empirical studies of students' fear of victimization in school have produced mixed results. For example, Addington (2003) found that the fear of victimization reported by US students aged 12-17 did not significantly change following the 1999 Columbine shootings. Other studies revealed an increased fear of victimization among secondary school students in Texas (Snell et al. 2002) and among female university students (Stretesky and Hogan 2001). A nuanced recent study of fear in 1500 schools revealed that students typically felt that their own schools were safer than average (Chapin and Coleman 2006). 
Highly publicized school shooting incidents also had an impact on school crime policy decisions, where these decisions were more frequently biased toward punitive policies. Frequently, school antiviolence policies were developed after school administrators received calls from parents (Snell et al. 2002), and these calls may be interpreted as evidence of public concern about school shootings generated by intense media coverage (Chenault 2004). In general, the USA takes a punitive response to juvenile offenders, but the USA might benefit from observing more restorative policies in Europe (Klein 2005a). One scholar (Webber 2003b) argues that the punitive approach adopted in the USA to combat school violence follows the military model of containment historically used to fight Communism. In this sense, youth are treated as a foreign enemy within domestic borders. At times, it appears that students in the USA are increasingly subject to surveillance programs instituted in the name of security, but which may increase the sense that schools are more analogous to correctional facilities, rather than nurturing institutions concerned with youth development (Dimitriadis and McCarthy 2003). In an attempt to cut through the hype surrounding the knee-jerk responses to violence in schools, Brooks et al. (2000) offered the following concrete policy recommendations: adding more context to media coverage, encouraging the use of punitive and meditative practices inside schools to maintain safety, and increased regulation of the gun industry.

Another interpretation of school-related shootings and violence is that these events are a threat to the public health and welfare (Elliott et al. 1998). Many studies concentrate on the mental health needs of the communities in which school shootings occur (Fast 2003; Fein 2003; Martin 2001; Weintraub et al. 2001; Windham et al. 2005). Another study in this tradition adopts a pragmatic approach that the emphasis should be on weapons-free schools, which might be achieved through entry-based weapons screening (Mawson et al. 2002).

Another variety of effect stems from the strong mass media dynamic present in school shootings, and this has sparked a number of studies. In a case study of the Dunblane shootings in Scotland, Jemphrey and Berrington (2000) demonstrated that mass media presence in communities following disastrous events may exacerbate the trauma experienced by the communities. However, the findings also indicate that many journalists are self-reflexive regarding their professional responsibilities toward the victims and communities where school shootings occur. This is especially important where the subjects of media attention are young. Some scholars have criticized the news media for their irresponsible handling of school shooting events (e.g. Muschert and Larkin forthcoming); however, journalists have reflected on their lessons learned by covering school shootings (Shepard 2003; Simpson and Coté 2006). Clearly it is psychologically difficult for media personnel to cover school shootings, especially when they occur in their own communities. One scholar examined the immediate challenges 
experienced by Denver Post journalists when they covered Columbine (Shepard 1999), and a related study demonstrated that the Columbine story had a long-lasting traumatic effect on the media personnel who covered it, especially those in the Denver area (Simpson and Coté 2006, 193-200).

\section{Concluding reflections}

Public and academic understanding of the phenomenon of school shootings is challenging, because there is a Rashomon effect derived from the varying sources of information. This article has attempted to clarify the distinction between the images of school shootings derived from two sources: First, social science studies paint the picture of school shootings as occurring at a relatively steady rate over recent decades. Second, news media accounts tended to concentrate on the apparent spate of school shootings occurring during the late 1990s and early 2000s. This purported wave of school shooting incidents contributed to the general impression that there was an emergent and increasing social problem of school shootings. As a problem on the public agenda, school shootings recently seem to have been supplanted by other social problems, which now seem more pressing. However, if we believe the social scientists, the status of school shootings has not changed much at all. In this article, I am making a call, echoed by others (e.g. Furlong et al. 2004; Kleck 1999), for continued research into the causes and effects of school shootings, despite the fact that it appears to be a subjective social problem that has declined. Continued research conducted by social scientists contributing to a more organized field of knowledge about school shootings would be most likely to contribute to effective public policy responses to respond to such incidents, or prevent them from occurring.

This article has also attempted to mitigate the Rashomon effect in the social scientific research in school shootings, through providing a comprehensive review of the findings from research in sociology, psychology, and media studies. Given the need to understand school shootings, a unified subfield is needed to move the discussion beyond what we have largely seen: idiosyncratic studies of single incidents written within a single field. To date, much of the research in school shootings has focused on a narrow range of cases that tend to be the higher-profile cases. While the initial impetus for the existing body of research may have emerged from the public outcry generated in the wake of incidents, such as Columbine, in the future, social scientists need to continue their research in a more proactive way. A longer-term, more-balanced approach to the study of school shooting incidents of various types and in varying settings is necessary for the emergence of a complex, even-handed understanding, which may ultimately lead to more sophisticated and proactive prevention and response strategies. 
In the spirit of organizing and orienting the future agenda of scholarship in school shootings, I offer the following suggestions for future research. First, there is a need for continued case study. Horror stories tend to dominate social problems research (Johnson 1995), and the dominance of high-profile rampage-type incidents in the school shootings research is telling. This article presents a typology of five varieties of school shooting incidents, and most studies to date have concentrated on the rampage and mass murder variety. Future case studies should expand the types of school-related shootings examined, and their location. Moore et al. (2003, 266-83) provide a useful road map for undertaking case studies that integrate crucial details of the case, including the details of the incident, community setting, school setting, background of the perpetrators, planning involved, community response, and legal disposition of the case.

Second, there is a need for comparative research across types of incidents, across nations, and across historical periods. The research field of school shootings has advanced to the point where it can be integrated into a more coherent body. This can be accomplished by selecting a variety of incidents for examination as a group, an approach that was nicely demonstrated in the cross-case analysis derived from individual case studies in Deadly Lessons (Moore et al. 2003, 247-64). Since school shootings are so complex, more research is warranted to understand these phenomena across differing social and cultural contexts. While many outside the USA may view school shootings as type of social malaise idiosyncratic to American society, in fact, these incidents have occurred in a variety of cultural settings, including an Amish community in Pennsylvania and a Native American Reservation in Minnesota, or in other countries, including Germany, Japan, and Canada. Since studies have identified a variety of social and cultural contexts for school shootings, cross-national comparative studies could help uncover the aspects of shootings that are idiosyncratic to the USA, versus those that are more widely diffused in varying cultural and international settings.

Third, there is a need for continued research into the media dynamics of school shootings. Most media studies have examined rampage shootings, but there is a need to broaden the focus of media research to include a wider variety of shootings. Again, the point here is to gain a broader understanding of the media dynamic by comparing across types and across nations, because the discourse about a given phenomenon can take greatly divergent forms when situated in different cultural contexts. An interesting quasi-experiment that remains untapped derives from an historical contingency that the news media were ejected from the community following the 2005 school shooting that occurred on the Red Lake Indian Reservation in Minnesota. Similarly, the Amish would have interacted with news media personnel in a different way than members of any other community experiencing a school shooting. These incidents stand out 
as interesting cases that might add to the body of media studies about school shootings.

Fourth, there are a number of promising aspects of school shootings that have not received attention from social scientists. To date there have been no victimology studies of the individuals targeted in these attacks, including students, faculty, and staff. Similarly, there has been little research examining the proximate and longer-term effects of such incidents on the communities in which they occur. In this regard, community impact studies might be warranted to uncover the effect of school shootings in a variety of settings, including urban, suburban, and rural communities. These impact studies might also examine the effects of school shootings on emergency personnel, including police, fire departments, ambulance crews, and medical personnel. Finally, school shootings have not been examined in the context of workplace violence, although this could be a rich area for future research. For students, school is analogous to a workplace, and for faculty and staff the school is their workplace.

This article has attempted to clarify the confusing Rashomon quality surrounding the phenomenon of school shootings, in an effort to organize a seemingly disparate body of research. Sadly, it is likely that school shootings will continue to occur. Despite a growing body of research concerning the causes of school shootings, it is unlikely that social scientists will identify a failsafe method for preventing such attacks. However, the continued study of a variety of school-related shooting incidents occurring in a variety of settings could lead to a greater understanding of the proximate and cultural causes behind such events, and their effects on the communities in which they occur. I offer this article in the spirit of motivating scholars in the social sciences to undertake the continued study of the variety of school shooting phenomena.

\section{Short Biography}

Glenn W. Muschert, a sociologist of social problems, is Criminology Program Coordinator and Assistant Professor in the Department of Sociology and Gerontology at Miami University in Oxford, Ohio. Dr. Muschert earned a BS in International Area Studies from Drexel University in 1992, and a Sociology PhD in 2002 from the University of Colorado at Boulder. After serving a 1-year appointment on Purdue University's Law \& Society faculty, he joined Miami University's Criminology faculty in 2003. His research focuses on social control through surveillance and the sociological implications of mass media coverage of high profile crimes, such as school shootings and child abductions. His research has appeared in Sociological Inquiry, Sociological Imagination, Annual Review of Law \& Social Science, Youth Violence \& Juvenile Justice, Justice Policy Journal, Journalism \& Mass Communication Quarterly, and Social Science Journal. 


\section{Acknowledgements}

The author wishes to thank J. Scott Brown, Jennifer Bulanda, Ronald Bulanda, Christine Caffrey, Leah Janssen, Anne Johnston, Ralph Larkin, Stephen Lippmann, Gary T. Marx, Anthony Peguero, and Christopher Wellin for their valuable assistance.

\section{Note}

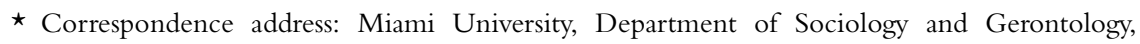
Oxford, Ohio 45056-1879, USA. Email: muschegw@muohio.edu.

\section{References}

Addington, Lynn A. 2003. 'Students' Fear after Columbine: Findings from a Randomized Experiment.' Journal of Quantitative Criminology 19: 367-87.

Aitken, Stuart C. 2001. 'Schoolyard Shootings: Racism, Sexism, and Moral Panics over Teen Violence.' Antipode 33: 593-600.

Altheide, David L. 2002a. 'Children and the Discourse of Fear.' Symbolic Interaction 25: 229-50.

Altheide, David L. 2002b. Creating Fear: News and the Construction of Crisis. New York: Aldine de Gruyter.

Arcus, Doreen 2002. 'School Shooting Fatalities and School Corporal Punishment: A Look at the States.' Aggressive Behavior 28: 173-83.

Aronson, Elliot 2004. 'How the Columbine High School Tragedy Could Have Been Prevented.' Journal of Individual Psychology 60: 355-60.

Bonilla, Denise M. 2000. School Violence. New York: H.W. Wilson.

Brooks, Kim, Vincent Schiraldi and Jason Ziedenberg 2000. School House Hype. Washington, DC: Justice Policy Institute.

Burgess, Ann, Christina Garbarino and Mary Carlson 2006. 'Pathological Teasing and Bullying Turned Deadly: Shooters and Suicide.' Victims \& Offenders 1: 1-13.

Burns, Ronald and Charles Crawford 1999. 'School Shootings, the Media, and Public Fear: Ingredients for Moral Panic.' Crime, Law, and Social Change 32: 147-68.

Caputo, Philip 2005. 13 Seconds: A Look Back at the Kent State Shootings. New York: Chamberlain Bros.

Catlaw, Thomas J. 2000. 'On Interpellation and Violence at Columbine.' Journal for the Psychoanalysis of Culture and Society 5: 338-42.

Center for Media and Public Affairs 1999. 'Violence Goes to School.' Media Monitor 13: 1-6.

Chapin, John and Grace Coleman 2006. 'Knowledge is Power: A Theory-Based Approach to Reducing School Violence.' Journal of Family Violence 21: 381-6.

Chenault, Scott 2004. 'An Overview of the Relationship between Juvenile School Shootings and the Media.' Journal of the Institute of Justice and International Studies 4: 101-11.

Chyi, Hsiang Iris and Maxwell McCombs 2004. 'Media Salience and the Process of Framing: Coverage of the Columbine School Shootings.' Journalism and Mass Communication Quarterly 81: 22-35.

CNN 2003. 'Police Search for Motive in School Shooting.' Retrieved January 26, 2007, from http://edition.cnn.com/2003/US/Northeast/04/24/school.shooting/index.html.

CNN 2006. 'Police: School Killer Told Wife He Molested Family Members.' Retrieved January 24, 2007, from http://edition.cnn.com/2006/US/10/03/amish.shooting/index.html.

Consalvo, Mia 2003. 'The Monsters Next Door: Media Constructions of Boys and Masculinity.' Feminist Media Studies 3: 27-45.

Cook, Daniel Thomas 2000. 'Childhood Is Killing “Our" Children: Some Thoughts on the Columbine High School Shootings and the Agentive Child.' Childhood 7: 107-17.

Cornell, Dewey G. 2006. School Violence: Fears Versus Facts. Mahwah, NJ: Lawrence Erlbaum Associates.

Curry, Vicky 2003. 'Thurston High School: The Effects of Both Distal and Emotional Proximity in an Acute Instance of School Violence.' Journal of School Violence 2: 93-120. 
Daniels, Jeffrey A., Ilene Buck, Susan Croxall, Julia Gruber, Peter Kime and Heidi Govert 2007. 'A Content Analysis of News Reports of Averted School Rampages.' Journal of School Violence 6: $83-99$.

DeJong, William, Joel C. Epstein and Thomas E. Hart 2003. 'Bad Things Happen in Good Communities: The Rampage Shooting at Edinboro, Pennsylvania, and Its Aftermath.' Pp. 70-100 in Deadly Lessons: Understanding Lethal School Violence, edited by Mark H. Moore, Carol V. Petrie, Anthony A. Braga and Brenda L. McLaughlin. Washington, DC: The National Academies Press.

Dimitriadis, Greg and Cameron McCarthy 2003. 'Creating a New Panopticon: Columbine, Cultural Studies, and the Uses of Foucault.' Pp. 273-92 in Foucault, Cultural Studies, and Governmentality, edited by Jack Z. Bratich, Jeremy Parker and Cameron McCarthy. Albany, NY: State University of New York Press.

Dinkes, Rachel, Emily Forrest Cataldi, Grace Kena, Katrina Baum and Thomas D. Snyder 2006. Indicators of School Crime and Safety: 2006. Washington, DC: U.S. Departments of Education and Justice.

Dunlop, John B. 2006. The 2002 Dubrovka and 2004 Beslan Hostage Crises: A Critique of Russian Counter-Terrorism. Stuttgart, Germany: Ibidem-Verlag.

Egendorf, Laura K. (ed.) 2002. School Shootings. San Diego, CA: Greenhaven Press.

Eglin, Peter and Stephen Hester 2003. The Montreal Massacre: A Story of Membership Categorization Analysis. Waterloo, ON: Wilfrid Laurier University Press.

Elliott, Delbert, Beatrix A. Hamburg and Kirk R. Williams 1998. Violence in American Schools. New York: Cambridge University Press.

Ellsworth, Monty J. 1927. 'The Bath School Disaster: Text \& Pictures.' Retrieved March 7, 2007, from http://www.msu.edu/ daggy/tbsd/tbsd-x.htm.

Fast, Jonathan D. 2003. 'After Columbine: How People Mourn Sudden Death.' Social Work 48: 484-91.

Fein, Albert 2003. There and Back Again: School Shootings as Experienced by School Leaders. Lanham, MD: Scarecrow.

Finley, Laura L. 2007. Encyclopedia of Juvenile Violence. Westport, CT: Greenwood Press.

Fox, Cybelle and David J. Harding 2005. 'School Shootings as Organizational Deviance.' Sociology of Education 78: 69-97.

Fox, Cybelle, Wendy D. Roth and Katherine Newman 2003. 'A Deadly Partnership: Lethal Violence in an Arkansas Middle School.' Pp. 101-31 in Deadly Lessons: Understanding Lethal School Violence, edited by Mark H. Moore, Carol V. Petrie, Anthony A. Braga and Brenda L. McLaughlin. Washington, DC: The National Academies Press.

Fullilove, Mindy T., Gina Arias, Moises Nunez, Ericka Phillips, Peter McFarlane, Roderick Wallace, and Robert E. Fullilove III 2003. 'What Did Ian Tell God?: School Violence in East New York.' Pp. 198-246 in Deadly Lessons: Understanding Lethal School Violence, edited by Mark H. Moore, Carol V. Petrie, Anthony A. Braga and Brenda L. McLaughlin. Washington, DC: The National Academies Press.

Furlong, Michael J., Gale M. Morrison, Dewey G. Cornell and Russell Skiba 2004. 'Methodological and Measurement Issues in School Violence Research: Moving Beyond the Social Problem Era.' Journal of School Violence 3(2/3): 5-12.

Glassner, Barry 1999. The Culture of Fear: Why Americans Are Afraid of the Wrong Things. New York: Basic Books.

Gunn, Joshua and David Beard 2003. 'On the Apocalyptic Columbine.' Southern Communication Journal 68: 198-216.

Hagan, John and Carla Shedd 2002. 'First and Last Words.' Sociological Methods E Research 31: 218-54.

Hagan, John, Paul Hirschfield and Carla Shedd 2003. 'Shooting at Tilden High: Causes and Consequences.' Pp. 163-97 in Deadly Lessons: Understanding Lethal School Violence, edited by Mark H. Moore, Carol V. Petrie, Anthony A. Braga and Brenda L. McLaughlin. Washington, DC: The National Academies Press.

Haider-Markel, Donald P. and Mark R. Joslyn 2001. 'Gun Policy, Opinion, Tragedy, and Blame Attribution: The Conditional Influence of Issue Frames.' Journal of Politics 63: 520-43.

Harding, David, Jal Metha and Katherine Newman 2003. 'No Exit: Mental Illness, Marginality, and School Violence in Wast Paducah, Kentucky.' Pp. 132-62 in Deadly Lessons: Understanding 
Lethal School Violence, edited by Mark H. Moore, Carol V. Petrie, Anthony A. Braga and Brenda L. McLaughlin. Washington, DC: National Academies Press.

Harter, Susan, Sabina M. Low and Nancy R. Whitesell 2003. 'What Have We Learned from Columbine: The Impact of Self-System on Suicidal and Violent Ideation Among Adolescents.' Journal of School Violence 2: 3-26.

Heck, William P. 2001. 'The School Shooter: One Community's Perspective.' FBI Law Enforcement Bulletin 70: 9-13.

Heider, Karl G. 1988. 'The Rashomon Effect: When Ethnographers Disagree' American Anthropologist 90: 73-81.

Henry, Stuart 2000. 'What Is School Violence? An Integrated Definition.' Annals of the American Academy of Political and Social Science 567: 16-29.

Hunnicut, Susan 2006. School Shootings. Farmington Hills, MI: Greenhaven Press.

Jacobs, Mark D. 2002. 'The School Shooting as a Ritual of Sacrifice.' Pp. 169-82 in Symbolic Childhood, edited by Daniel Thomas Cook. New York: Peter Lang.

Jacoby, Jeff 2004. 'Arafat the Monster.' Boston Globe, November 11, 2004.

Jemphrey, Ann and Eileen Berrington 2000. 'Surviving the Media: Hillsborough, Dunblane and the Press.' Journalism Studies 1: 469-83.

Johnson, John M. 1995. 'Horror Stories and the Construction of Child Abuse.' Pp. 17-31 in Images of Issues: Typifying Contemporary Social Problems (2nd edn.), edited by Joel Best. Hawthorne, NY: Aldine de Gruyter.

Kimmel, Michael S. and Matthew Mahler 2003. 'Adolescent Masculinity, Homophobia, and Violence.' American Behavioral Scientist 46: 1439-58.

Kirk, Michael, Miri Navasky and Karen O'Connor 2000. Frontline: The Killer at Thurston High. Alexandria, VA: PBS Video.

Kleck, Gary 1999. 'There Are No Lessons to Be Learned from Littleton.' Criminal Justice Ethics 18: $60-3$.

Klein, Jesse 2005a. 'America Is from Mars, Europe Is from Venus: How the United States Can Learn from Europe's Social Work Response to School Shootings.' School Social Work Journal 30: $1-24$.

Klein, Jessie 2005b. 'Teaching Her a Lesson: Media Misses Boy's Rage Relating to Girls in School Shootings.' Crime, Media, Culture 1: 90-7.

Klein, Jessie 2006. 'Cultural Capital and High School Bullies.' Men and Masculinities 9: 53-75.

Kurosawa, Akira 1969. Rashomon: A Film by Akira Kurosawa. New York: Grove Press.

Larkin, Ralph 2007. Comprehending Columbine. Philadelphia, PA: Temple University Press.

Lawrence, Regina G. 2001. 'Defining Events: Problem Definition in the Media Arena.' Pp. 91-110 in Politics, Discourse, and American Society: New Agendas, edited by Roderick P. Hart and Bartholomew H. Sparrow. Lanham, MD: Rowman \& Littlefield.

Lawrence, Regina G. and Thomas A. Birkland 2004. 'Guns, Hollywood, and School Safety: Defining the School-Shooting Problem across the Public Arenas.' Social Science Quarterly 85: 1193-207.

Leary, Mark R., Robin M. Kowalski, Laura Smith and Stephen Phillips 2003. 'Teasing, Rejection, and Violence: Case Studies of the School Shootings.' Aggressive Behavior 29: 202-14.

Levin, Jack and James A. Fox 1999. 'Making Sense of Mass Murder.' Pp. 173-87 in Handbook of Psychological Approaches to Violent Offenders, edited by Vincent B. van Hasselt and Michel Hersen. Norwell, MA: Kluwer Academic.

Levin, Jack and James A. Fox 2001. Dead Lines: Essays in Murder and Mayhem. Neeham Heights, MA: Allyn \& Bacon.

Lickel, Brian, Toni Schmader and David Hamilton 2003. 'A Case of Collective Responsibility: Who Else Was to Blame for the Columbine High School Shootings?' Personality \& Social Psychology Bulletin 29: 194-204.

Maguire, Brendan, Georgie Ann Weatherby and Richard A. Mathers 2002. 'Network News Coverage of School Shootings.' Social Science Journal 39: 465-70.

Mai, Rebecca and Judith Alpert 2000. 'Separation and Socialization: A Feminist Analysis of the School Shootings at Columbine.' Journal for the Psychoanalysis of Culture and Society 5: 264-75.

Martin, Irene Rodriguez 2001. 'Constructing a Community Response to Violence.' Smith College Studies in Social Work 71: 347-55. 
Mawson, Anthony R., Peter M. Lapsley, Allan M. Hoffman and John C. Guinard 2002. 'Preventing Lethal Violence in Schools: The Case for Entry-Based Weapons Screening.' Journal of Health Politics, Policy and Law 27: 243-60.

McCabe, Kimberly A. and Gregory M. Martin 2005. School Violence, the Media, and Criminal Justice Responses. New York: Peter Lang Pub.

McGee, James P. and Caren R. DeBernardo 1999. 'The Classroom Avenger: A Behavioral Profile of School Based Shootings.' The Forensic Examiner 8: 16-8.

McGee, James P. and Caren R. DeBernardo 2002. 'The Classroom Avenger.' Pp. 230-49 in Handbook of Juvenile Forensic Psychology, edited by Neil G. Ribner. San Francisco, CA: Jossey-Bass.

Meloy, J. Reid, Anthony Hempel, Kris Mohandie, Andrew A. Shive and B. Thomas Gray 2001. 'Offender and Offence Characteristics of a Nonrandom Sample of Adolescent Mass Murderers.' Journal of the American Academy of Child and Adolescent Psychiatry 40: 719-28.

Moore, Mark H., Carol V. Petrie, Anthony A. Braga and Brenda L. McLaughlin 2003. Deadly Lessons: Understanding Lethal School Violence. Washington, DC: National Academies Press.

Muschert, Glenn W. 2007. 'The Columbine Victims and the Myth of the Juvenile Superpredator.' Youth Violence and Juvenile Justice 5(4) Forthcoming.

Muschert, Glenn W. (forthcoming). 'Frame-Changing in the Media Coverage of a School Shooting: The Rise of Columbine as a National Concern.' Social Science Journal.

Muschert, Glenn W. and Dawn Carr 2006. 'Media Salience and Frame Changing across Events: Coverage of Nine School Shootings.' Journalism \& Mass Communication Quarterly 83: 747-66.

Muschert, Glenn W. and Ralph W. Larkin (forthcoming). 'The Columbine High School Shootings.' In Crimes of the Century, edited by Frankie Bailey and Steve Chermak. Westport, CT: Praeger.

National School Safety Center 2007. 'School Associated Violent Deaths.' Retrieved February 2, 2007, from http://www.schoolsafety.us/pubfiles/savd.pdf.

Nelson, Jack and Jack Bass 1970. The Orangeburg Massacre. New York: World Publishing.

Neroni, Hilary 2000. 'The Men of Columbine: Violence and Masculinity in American Culture and Film.' Journal for the Psychoanalysis of Culture and Society 5: 256-63.

Newman, Katherine 2004. Rampage: The Social Roots of School Shootings. New York: Basic Books.

Ogle, Jennifer Paff, Molly Eckman and Catherine Amoroso Leslie 2003. 'Appearance Cues and the Shootings at Columbine High: Construction of a Social Problem in the Print Media.' Sociological Inquiry 73: 1-27.

Repenning, Kari, Heather Powell, Amy Doane and Heather Dunkle 2001. 'Demystifying School Violence: A Local, State, and National Perspective on the Phenomenon of School Violence.' Journal of Security Administration 24: 45-63.

Roth, Wendy D. and Jal D. Mehta 2002. 'The Rashomon Effect: Combining Positivist and Interpretivist in the Analysis of Contested Events.' Sociological Methods and Research 31: 131-73.

Samuels, Robert 2000. 'From Columbine to Professional Wrestling: Psychoanalysis of Postmodern Media Violence.' Journal for the Psychoanalysis of Culture and Society 5: 312-8.

Sandler, Pamela and Judith L. Alpert 2000. 'Violence and Group Dynamics in the High School: The Columbine School Shootings.' Journal for the Psychoanalysis of Culture and Society 5: 246-55.

Scharrer, Erica, Lisa M. Wiedman and Kimberly L. Bissel 2003. 'Pointing the Finger of Blame: News Media Coverage of Popular-Culture Culpability.' Journalism \& Communication Monographs 5: 49-98.

Schiele, Jerome H. 2001. 'When White Boys Kill: An Afrocentric Analysis.' Journal of Human Behavior in the Social Environment 4: 253-73.

Shepard, Alicia C. 1999. 'Covering the Big One.' American Journalism Review 21: 22-9.

Shepard, Alicia C. 2003. 'Columbine School Shooting: Live Television Coverage.' Pp. 57-81 in Thinking Clearly: Cases in Journalistic Decision-Making, edited by Tom Rosenthiel and Amy S. Mitchell. New York: Columbia University Press.

Simpson, Roger and William Coté 2006. Covering Violence: A Guide to Ethical Reporting about Victims and Trauma. New York: Columbine University Press.

Smit, Christopher R. 2001. 'Columbine: An Exploration of the Hyperreal in Television Chaos.' Pp. 88-101 in Ordinary Reactions to Extraordinary Events, edited by Ray B. Browne and Arthur G. Neal. Bowling Green, OH: Bowling Green University Popular Press. 
Snell, Clete, Charles Bailey, Anthony Corona and Dalila Mebane 2002. 'School Crime Policy Changes: The Impact of Recent Highly-Publicized School Crimes.' American Journal of Criminal Justice 26: 269-85.

Stein, Howard F. 2000. 'Disposable Youth: The 1999 Columbine High School Massacre as American Metaphor.' Journal for the Psychoanalysis of Culture and Society 5: 217-36.

Stretesky, Paul B. and Michael J. Hogan 2001. 'Columbine and Student Perceptions of Safety: A Quasi-experimental Study.' Journal of Criminal Justice 29: 429-43.

Sullivan, Mercer L. 2002. 'Exploring Layers.' Sociological Methods \& Research 31: 255-85.

Sullivan, Mercer L. and Rob T. Guerette 2003. 'The Copycat Factor: Mental Illness, Guns, and the Shooting Incident at Heritage High School, Rockdale County, Georgia.' Pp. 2569 in Deadly Lessons: Understanding Lethal School Violence, edited by Mark H. Moore, Carol V. Petrie, Anthony A. Braga and Brenda L. McLaughlin. Washington, DC: The National Academies Press.

Tonso, Karen L. 2003. 'Reflecting on Columbine High: Ideologies of Priviledge in "Standardized" Schools.' Educational Studies 33: 389-403.

Vossekuil, Bryan, Marissa Reddy and Robert Fein 2000. 'Safe School Initiative: An Interim Report on the Prevention of Targeted Violence in Schools.' Washington, DC: U.S. Secret Service National Threat Assessment Center, U.S. Department of Education, and National Institute of Justice.

Vossekuil, Bryan, Marissa Reddy, Robert Fein, Randy Borum and William Modzeleski 2002. 'The Final Report and Findings of the Safe School Initiative: Implications for the Prevention of School Attacks in the United States.' Washington, DC: U.S. Secret Service and U.S. Department of Education.

Watson, Justin 2002. The Martyrs of Columbine: Faith and the Politics of Tragedy. New York: Palgrave Macmillan.

Webber, Julie A. 2003a. Failure to Hold: The Politics of School Violence. New York: Rowman \& Littlefield Publishers.

Webber, Julie A. 2003b. 'Post-Columbine Reflections on Youth Violence as a (Trans)National Movement.' Pp. 189-201 in Education as Enforcement: The Militarization of Schools, edited by Kenneth J. Salkman and David A. Gabbard. New York: RoutledgeFalmer.

Weintraub, Phillippe, Harriet L. Hall and Robert S. Pynoos 2001. 'Columbine High School Shootings: Community Response.' Pp. 129-61 in School Violence: Assessment, Management, Prevention, edited by Mohammad Shafii and Sharon Lee Shafii. Washington, DC: American Psychiatric Publishing.

Windham, R. Craig, Lisa M. Hooper and Patricia E. Hudson 2005. 'Selected Spiritual Religious, and Family Factors in the Prevention of School Violence.' Counseling \& Values 49: 208-16. 